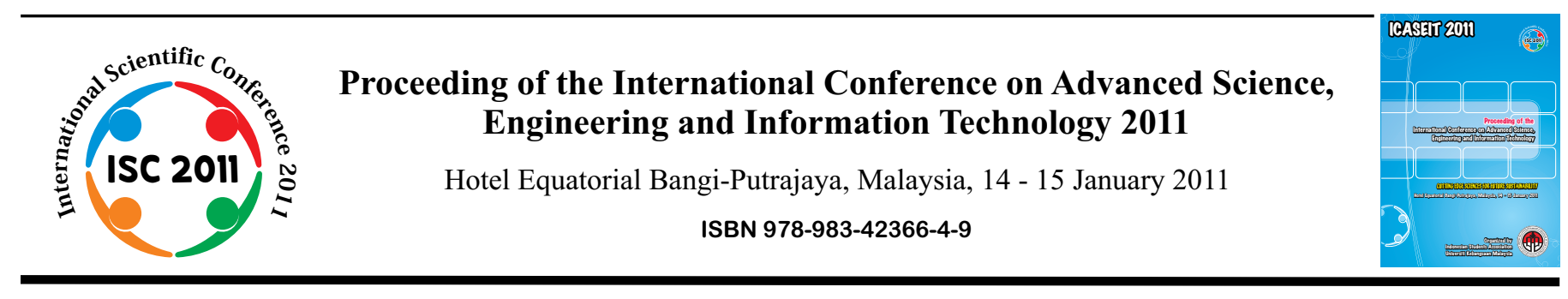

\title{
Isolation of Lactobacillus salivarius from Children and Purification of Bacteriocin to Inhibition Cancer Cell in Vitro
}

\author{
AL-Tememy Waleed K.M ${ }^{\mathrm{a}}$, AL-Ani Ibraem A ${ }^{\mathrm{b}}$, AL-Ani Mohammed.Q ${ }^{\mathrm{c}}$, Al alusi Nadia T ${ }^{\mathrm{d}}$, Salmah, $\mathrm{I}^{\mathrm{d}}$ \\ ${ }^{a}$ Department of Basic Science, university of AL-Anbar ,Faculty of Dentistry, Ramady,00964024,Iraq \\ $b$ Department of Basic Science, university of AL-Anbar,Faculty of Veterinary Medicine,Ramady,00964024,Iraq \\ c Department of Medical Physiology, university of AL-Anbar ,Faculty of science,Ramady,00964024,Iraq \\ $d$ Department of Molecular Medicine ,university of Malaya, Faculty Medicine, 50603 Kuala Lumpur \\ Tel.:+96407816684666,E-mail:waledaltememy@yahoo.com
}

\begin{abstract}
Bacteria being used to make anticancer agents could provide an extra source of lead compounds for the pharmaceutical industry. Bacterium Lactobacillus salivarius produce compounds that selectively inhibit growth of human cancer cells Lactobacillus salivarius naturally produces a compound called Bacteriocins. Bacteriocins are bacterial proteins produced to prevent the growth of competing microorganisms in a particular biological niche and we can use it as antineoplastic. The aim of this study was to isolate bacteriocin produced by lactic acid bacteria. A preparation of bacteriocin from a strain Lactobacillus salivarius has long been shown to have antineoplastic activity against a variety of human tumor and animal tumor cell lines in vitro. A total of 60 LAB were isolated from children stool 45 isolate showed a clear antimicrobial activity against indicator strain Streptococcus aureus and by used sodium phosphate buffer (pH8) from an $80 \%$ ammonium sulfate precipitate. The inhibition activity was determent by well diffusion assay method technique, Bacteriocin purification processes were carried out by using ion-exchange (Trisacryl SP) and gel filtration chromatography (Sephacryl - S300). The apparent molecular mass of partially purified bacteriocin was $15.848 \mathrm{kDa}$, Cell Culture was maintained in RPMI 1640 medium supplemented with $10 \%$ (vol/vol) fetal calf serum, Cytotoxicity of bacteriocin was assessed on human cell line (RD) and animal cell line (MDCK) cell viability after incubation for $48 \mathrm{~h}$ in medium containing 500AU/ml (1.15 $\mathrm{mg} / \mathrm{ml}$ ). Both cell types used in this study were sensitive to bacteriocin and the bacteriocin appeared to inhibit proliferation of tumor cell line. The animal cell line was more sensitivity than human cell line.
\end{abstract}

Keywords - Lactobacillus salivarius, Bacteriocins, ion-exchange, tumor cell line .

\section{INTRODUCTION}

Cancer represents one of the most serious health problems worldwide[1] and the improvement of new anticancer therapy and more effective treatment strategies are fields of utmost importance in drug discovery and clinical therapy [2]. A lot of the research in these areas is nowadays focusing on cancer-specific mechanisms and the corresponding molecular targets (e.g., kinases related to cell cycle progression or signal transduction) but the search for improved cytotoxic agents (acting on ubiquitous targets such as DNA) still represent an important part of new anticancer drug innovation (Xiao-Tian Liang and Wei-Shuo fang 2006) . Bacteriocins are small peptides $(30-60)$ amino acid with antimicrobial properties against bacteria usually of the same or closely related species (narrow spectrum), andsometimes against a wide spectrum of species [3], [4],
[5], [6], Microorganisms that produce bacteriocins also have immunity mechanisms to present self - protection from committing "suicide" [7], [8].

Cancer, differentiate by uncontrolled growth and spread of abnormal cells, due to external and internal factors. Environmental factors and chemical carcinogens play a predominant role in the induction of DNA lesions and other genomic abnormalities [9], Innovation of anticancer drug is always an attractive challenge and are classified in different ways according to their nature, sources, mechanisms of action etc, which may be of microbial products, synthetic chemicals, plant or animal extracts [10]. Because of recent advances in peptide therapeutic, bacteriocin is presented as a therapeutic agent and its biochemical properties have been studied, Bacteriocin antineoplastic capability has been 
insufficiently discovered in the late 1970s by using crude bacteriocin preparation toxic to mammalian cells [11], purified bacteriocins are obtainable and have shown inhibitory properties against different neoplastic line cells, Pyocin, colicin, ped-iocin, and microcin are among bacteriocins reported to present such activity [12], Moreover, modified bacteriocins proved to be effective in a glioblastoma xenograft mouse model [11].

\section{MATERIALS AND METHODS}

\section{A. Bacteria in rectal swab samples}

In total, 60 samples were collected by rectal swabs from children in AL-Faluja hospital-Iraq and were kept in sterile tubes containing MRS broth media and then inoculated on plates of MRS (Man-Rogosa-Sharpe medium) Agar pH 6.2 (Hi-media, India) and incubated at $37^{\circ} \mathrm{C}$ aerobically $5 \%$ $\mathrm{CO} 2$ conditions (Gas Pak system) for $48 \mathrm{~h}$, then sub cultured on Man-Rogosa-Sharpe medium (MRS) agar for $48 \mathrm{~h}$. The growing colonies were characterized by phenotypical properties including morphology, gram positive staining and absence of catalase, oxidase and motility [13], [14] .

\section{B. Classification of isolates}

Only isolates of gram-positive rods and catalase negative were considered for further identification. Tests for catalase were made by adding $5 \mathrm{ml}$ of $3 \%$ hydrogen peroxide to the cell pellet obtained by centrifuging (12,000 x g for $10 \mathrm{~min})$ $10 \mathrm{ml}$ of an MRS broth culture. Cultures were considered catalase negative if no visible gassing was observed. Cultures were examined for growth at $15^{\circ} \mathrm{C}$ and $45^{\circ} \mathrm{C}$ in MRS broth and for gas production by the methods of [15] for the latter, $5 \mathrm{ml}$ of $1.5 \%$ sterile agar was used as the overlay.

MRS broth with glucose and beef extract omitted [16] was the basal medium used for determination of ammonia production from arginine, esculin hydrolysis, and carbohydrate fermentations. Esculin hydrolysis and ammonia production were determined as described by Davis[17]. Ability of cultures to fermentation of carbohydrates were determined as described by Schillinger and Lücke [18]. The carbohydrates tested were Galactose, Glucose, Ribenose, Manitol, Lactose, Xylose and Maltose(Merck, Darmstadt, Germany) and sterile water were used as negative controls. Cultures of anaerobic organisms were incubated in a Gas Pak system .

\section{Screening of isolates for antimicrobial activity}

There are several screening methods available to detect antimicrobial activity from supernatants, spot-on-lawn assay [19], disc diffusion [20], microtiter plate assay [21], agar well diffusion assay [22], multi-well plate assay[23], in this studied Antimicrobial activity of Lact.salivarus against Staphylococcus aureus was determined by well diffusion method under aerobic conditions. Agar plates were inoculated with $100 \mu \mathrm{l}$ of each target microorganism after growing them in a broth and diluting appropriately. Wells (5 $\mathrm{mm})$ were made in the agar and $100 \mu \mathrm{l}$ of cell-free culture supernatant fluid of the isolated strain was placed into each well. The inhibition activity against Staphylococcus aureus were tested on nutrient agar. Plates were kept at $4^{\circ} \mathrm{C}$ for $2 \mathrm{~h}$ and then incubated at $37{ }^{\circ} \mathrm{C}$ for $24 \mathrm{~h}$. The antimicrobial activity was determined by measuring the diameter of the inhibition zone around the wells. The bacterial isolate of widest zone of inhibition against the target microorganism was selected for further studies. The inhibition activity was expressed quantitatively as arbitrary units per milliliter $(\mathrm{AU} / \mathrm{mL})$. The arbitrary unit (AU) was defined as the reciprocal of the highest dilution able to produce a clear zone of growth inhibition of the indicator strain.

\section{Concentration of the bacteriocin containing supernatant by used Ammonium sulfate precipitation}

To begin characterization of a new antimicrobial peptide is important to decide and to implement a purification strategy. Many LAB bacteriocins are not produced in high amounts by the producer strain; therefore it is very important to concentrate the supernatant that contains the antimicrobial substance at the very initial steps. For this purpose, many protocols have been implemented ammonium sulfate concentration. Isolated strain having maximum antimicrobial zone was grown in MRS broth at $37{ }^{\circ} \mathrm{C}$ for $24 \mathrm{~h}$. After incubation, the broth was centrifuged at $(5000 \times \mathrm{g}$ for $10 \mathrm{~min}$ $4^{\circ} \mathrm{C}$ ) and the cells were separated out. Supernatant was used as a crude bacteriocin and the peptide fraction precipitated from the cell-free supernatant with $80 \%$ saturated ammonium sulphate [22], After stirring on a magnetic stirrer, it was kept undisturbed at $4{ }^{\circ} \mathrm{C}$ overnight. Precipitates formed were collected by centrifugation at $10000 \times \mathrm{g}$ for $10 \mathrm{~min}$ and re dissolved in $20 \mathrm{mmol}$ sodium phosphate buffer with $\mathrm{pH}=6$.0. Inhibition zone of different fractions was recorded in comparison with the crude bacteriocin.

\section{E. Purification of bacteriocins}

The crude bacteriocin was precipitated with $80 \%$ ammonium sulphate saturation .The methodology described above produces a partially purified extract of bacteriocins. These extracts must be subjected to other purification step. The most frequenly used techniques are Ion Exchange Chromatography (IEC) by Trisacryl SP and Gel filtration by Sephacryl - S300 .

\section{F. Determination of protein}

Protein concentration of the bacteriocin in supernatant was determined by the method of [23], using bovine serum albumin as the standard.

\section{G. Ion Exchange Chromatography:}

The Ion Exchange chromatography could be used either with cation or anion exchange resins that are able to separate the peptides by their electric charge at definite $\mathrm{pH}$. Since most bacteriocins have positive charges at $\mathrm{pH}$ near neutrality, the use of cation exchange resins is appropriate for their purifications. In this study a standard protocol was used, the bacteriocin extract was passed through the cation-exchange column, washed with a phosphate buffer containing $\mathrm{NaCl}$ at concentration of 0.1 to $1.0 \mathrm{M}$ then Trisacryl SP columns was packaged with a strong-cation exchange resin (Mega-BE $\mathrm{SCX}$, Varian). The flow rate was $0.5 \mathrm{ml} / \mathrm{min}$. Five $\mathrm{ml}$ 
fractions were collected, by using well diffusion methods methods antibacterial activity was measured for sensitive strain. The extract is stored at $-20{ }^{\circ} \mathrm{C}$.

\section{H. Molecular weight determination in Gel filtration Chromatography}

The molecular weight of the bacteriocin was determined by Gel filtration chromatography (Sephacryl - S300) chymotrypsinogen A, Bovine serum albumin, Ovalbumine and Ribinuclase A was applied to a Sephacryl - S300 column $(2.5$ by $40 \mathrm{~cm})$ and equilibrated with $0.05 \mathrm{M}$ phosphate buffer ( $\mathrm{pH} 7.0$ ) containing $0.15 \mathrm{M} \mathrm{NaCl}$. The column was eluted with this buffered saline. Cells were maintained as exponentially growing monolayer's in RPMI 1640 supplemented with 10\% (v/v) FCS (Sigma, Poole, United Kingdom).

\section{Cytotoxicity Assays}

The human cell lines (RD) and animal cell line (MDCK) were grown as a monolayer culture in Rosswell Park Memorial Institute (RPMI-1640) medium (Sigma, Poole, United Kingdom), supplemented with $10 \%$ Bovine calf serum ( BCS )(GIBCO), 1000 units/ml penicillin, and 100 $\mathrm{mg} / \mathrm{ml}$ streptomycin (Life Technologies, Inc., Paisley, United Kingdom) [26]. The cultures were maintained at $37{ }^{\circ} \mathrm{C}$ in a humidified $5 \% \mathrm{CO} 2$ condition. After the formation of a monolayer, the cell line was prepared for cytotoxicity assay by treating them with trypsin/versine. An amount of $0.2 \mathrm{ml}$ of cells suspension was mixed with $0.2 \mathrm{ml}$ of trypan blue solution and $1.6 \mathrm{ml}$ PBS. Viable cells do not stain, whereas dead cells stained with blue color as seen under the light microscope[27], The formula found by Freshney was used to calculate the number of cells per millimetre[28], $10^{6}(20 \mu \mathrm{l})$ Cells were seeded in 96-well plate then bacteriocin was added 500AU/ml $(1.15 \mathrm{mg} / \mathrm{ml})$. Finally, cell viability was assesd after incubation for $48 \mathrm{~h}$.

\section{RESULTS}

Bacteriocin producer strain was isolated from children's Rectal swab in AL-Falluja hospital and the selected strain was identified by its physiological and biochemical characteristic (Table 1).

Table 1: Physiological an d Biochemical Characteristic

\begin{tabular}{|l|l|}
\hline $\begin{array}{c}\text { Physiological and biochemical } \\
\text { characteristic }\end{array}$ & \multicolumn{1}{|c|}{ Result } \\
\hline Colony Morphology & $\begin{array}{l}\text { Creamy, little sticks and smooth } \\
\text { and convex colonies }\end{array}$ \\
\hline Gram staining & Gram positive, pleomorphic rod \\
\hline Growth in MRS broth & uniform turbidity \\
\hline Type of fermentation & Homo fermentative \\
\hline $\begin{array}{l}\text { Galactose, Glucose, Ribenose, } \\
\text { Manitol, Lactose, Xylose Maltose }\end{array}$ & Fermentation positive \\
\hline Catalase, Oxidase, Indole & Negative \\
\hline Nitrate Reduction & Negative \\
\hline H2S production & Negative \\
\hline Gram staining & Fermentation positive \\
\hline
\end{tabular}

\section{A. Determination of inhibitory spectrum}

The growing of Staphylococcus aureus was inhibited ( $25 \mathrm{~mm})$ by using the supernatant of Lactobacillus salivarius to the right side in (Fig.1). The inhibition zone $(16.5 \mathrm{~mm})$ in the middle of (Fig.1) shows the inhibition activity against, Staphylococcus aureus, by using purified bacteriocin.

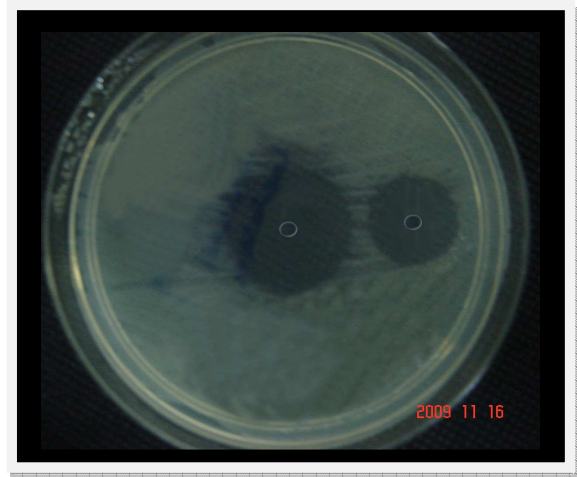

(Fig 1) Bacteriocin activity against Staphylococcus aureus by agar-well diffusion method

\section{B. Purification of bacteriocin}

In the purification step of filtrate culture the proteins were concentrated by $80 \%$ ammonium sulphate precipitation. The recovered proteins were then fractionated by ion-exchange chromatography, using Trisacryl SP. All procedures were done in cold room. The overall yield and activity are summarized in Table 2.

Table 2: Summary of the purification steps of bacteriocin from the culture supernatant of Lact .salivarus

\begin{tabular}{|c|c|c|c|}
\hline $\begin{array}{c}\text { Purification } \\
\text { Stage }\end{array}$ & $\begin{array}{c}\text { Culture } \\
\text { supernatant }\end{array}$ & $\begin{array}{c}\text { Ammonium } \\
\text { sulphate } \\
\text { precipitation } \\
\mathbf{8 0 \%} \\
\text { saturation }\end{array}$ & $\begin{array}{c}\text { Trisacryl SP } \\
\text { chromatography }\end{array}$ \\
\hline Volume (ml) & 200 & 25 & 40 \\
\hline $\begin{array}{c}\text { Activity (unit } \\
\text { /ml) }\end{array}$ & 290 & 456 & 500 \\
\hline $\begin{array}{c}\text { Total activity } \\
\text { (AU /ml) }\end{array}$ & 58000 & 11400 & 20000 \\
\hline $\begin{array}{c}\text { Total protein } \\
\text { (mg) }\end{array}$ & 12.5 & 18.6 & 1.15 \\
\hline $\begin{array}{c}\text { Speci-fic } \\
\text { activity }\end{array}$ & 23.2 & 24.5 & 434.8 \\
\hline Purification & 1 & 1.06 & 18.74 \\
\hline Recovery (\%) & 100 & 19.6 & 34.5 \\
\hline \multicolumn{2}{|c|}{} \\
\hline \multicolumn{2}{|c|}{}
\end{tabular}

Treatment of all types of cell lines with different concentrations of bacteriocin showed highly significant inhibitory effect on growth of the cell lines. All concentrations starting from $18.6 \mathrm{mg} / \mathrm{ml}$ of crude bacteriocin after treatment for $48 \mathrm{hrs}$ significantly reduced the growth rate of RD and MDCK cell lines(Table-3) compare to control group which showed complete confluent monolayer of cohesive cells (Figure-2,3-a, b,) 
(Table-3) The effect of Bacteriocin and Crude protein on the growth of MRCK cell lines after $48 \mathrm{hrs}$ in vitro

\begin{tabular}{|c||c||c|}
\hline \multirow{2}{*}{$\begin{array}{c}\text { Concentration } \\
\text { of material } \\
\text { mg/ml }\end{array}$} & \multicolumn{2}{|c|}{ Ratio of Inhibition } \\
\cline { 2 - 3 } & $\begin{array}{c}\text { Crude } \\
\text { protein }\end{array}$ & Bacteriocin \\
\hline \hline 0.575 & 0 & 25.8 \\
\hline 0.288 & 13.9 & 24.6 \\
\hline 0.144 & 0 & 19.2 \\
\hline 0.072 & 7.8 & 19.2 \\
\hline 0.036 & 0 & 6.6 \\
\hline 0.018 & 0 & 4.8 \\
\hline 0.009 & 0 & 5.5 \\
\hline 0.0045 & 0 & 0 \\
\hline
\end{tabular}

(Table-4) The effect of Bacteriocin and Crude protein on the growth of $\mathrm{RD}$ cell lines after $48 \mathrm{hrs}$ in vitro

\begin{tabular}{|c|c|c|}
\hline \multirow{2}{*}{$\begin{array}{c}\text { Concentration } \\
\text { of material } \\
\text { mg/ml } \\
\text { Bacteriocin }\end{array}$} & \multicolumn{2}{|c|}{ Ratio of Inhibition } \\
\hline & $\begin{array}{l}\text { Crude } \\
\text { protein }\end{array}$ & Bacteriocin \\
\hline 5.9 & $\mathbf{0}$ & 5.9 \\
\hline 4.8 & $\mathbf{0}$ & 4.8 \\
\hline 3.0 & 7.2 & 3.0 \\
\hline 3.6 & 14.5 & 3.6 \\
\hline $\mathbf{0}$ & $\mathbf{0}$ & $\mathbf{0}$ \\
\hline $\mathbf{0}$ & $\mathbf{0}$ & $\mathbf{0}$ \\
\hline $\mathbf{0}$ & $\mathbf{0}$ & $\mathbf{0}$ \\
\hline $\mathbf{0}$ & $\mathbf{0}$ & $\mathbf{0}$ \\
\hline
\end{tabular}

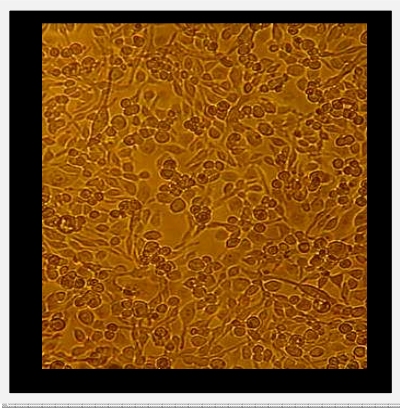

(A)

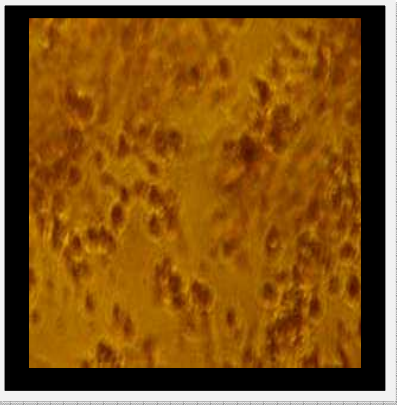

(B)
Figure. 2 The effect of Bacteriocin on the growth of MRCK cell line A= control, $\mathrm{B}=$ cells treated with $0.575 \mathrm{mg} / \mathrm{ml}$ of Bacteriocin.
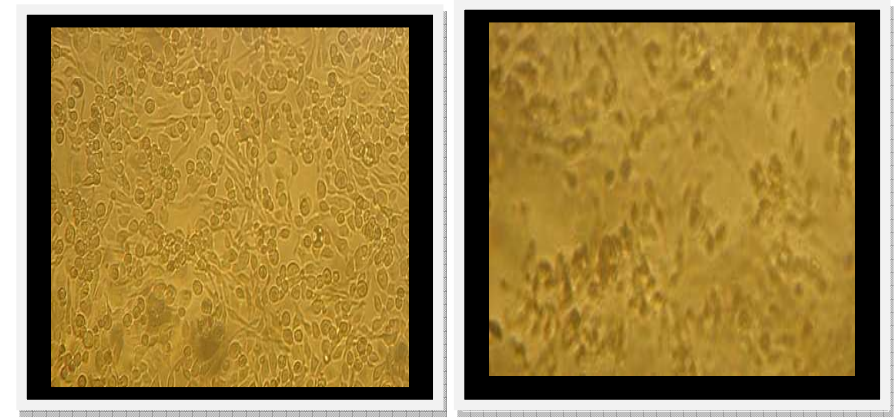

Figure. 3 The effect of Bacteriocin of Lact .salivarus on the growth of RD cell line $\mathrm{A}=$ control, $\mathrm{B}=$ cells treated with $0.575 \mathrm{mg} / \mathrm{ml}$ from Bacteriocin

\section{DISCUSSION}

Bacterial Lactic acid is widely used as antimicrobial and anticancer agent. Bacteriocin in this study was extracted by cell free supernatant method and the crude supernatant was assessed for its antagonistic activity. The inhibition effect of L.salivirus against Staph.aureus is an indication for antibacterial activity and this result matchs several studies which considered bacteriocin as an antibiotic for many diseases and anticancer [11], [29]. Such activity may be due to a variety of compounds (fatty acids and peroxides, etc.) produced by the antagonistic isolate[30], Moreover, bacteriocins consist of bactericidal polypeptides with a mechanism of action similar to that of ionosphere antibiotics [31], The occurrence of bacteriocin production among Lactobacillus.spp. in competitive, complex microbial communities suggests that bacteriocins may have a regulatory role for population dynamics within bacterial ecosystems [32], Our bacterium-derived compound met the criteria for being considered a bacteriocin. The cytotoxicity of bacteriocin was investigated on RD and MDCK cell lines of cancer. The cytotoxicity assay results indicate that bacteriocins have a cytotoxic effect on neoplastic human and animal cell lines. The effect on cells from animal origin is more than human origin.

The cancer cell line presented different sensibility to bacteriocin, since MDCK cell lines viability gradually decreased in number with increasing of bacteriocin concentrations. Bacteriocin was harmless between 0.012 and $0.0015 \mathrm{mg} / \mathrm{ml}$ to $\mathrm{RD}$ cell line over $48 \mathrm{~h}$ while MRCK cell line was harmless in $0.0045 \mathrm{mg} / \mathrm{ml}$ this differential cytotoxicity may be related to differences in plasma membrane composition and metabolic activity of target cells. [33].Moreover,

The difference on the cell surface hydrophobicity may influence the effective binding and cytotoxic action. In conclusion, Bacteriocins produced by L. salivirus have the potential to cover a very broad field of application, including the medical sector. The ease of bacteriocin extraction and because it is safe and non-toxic to humans and animals cells, while it is lethal to the cancer cells line as complete monolayer's is rapidly killed give bacteriocin chance to be considered as anticancer agent. 


\section{References}

[1] T. Ngoma, "World Health Organization cancer priorities in developing countries," Annals of oncology, vol. 17, no. suppl 8, 2006.

[2] G. Peters, Deoxynucleoside analogs in cancer therapy: Humana Pr Inc, 2006.

[3] T. Klaenhammer, "Bacteriocins of lactic acid bacteria," Biochimie, vol. 70, no. 3, pp. 337-349, 1988.

[4] K. Rantsiou, E. Drosinos, M. Gialitaki et al., "Use of molecular tools to characterize Lactobacillus spp. isolated from Greek traditional fermented sausages," International journal of food microbiology, vol. 112, no. 3, pp. 215-222, 2006.

[5] A. Galvez, R. Lopez, H. Abriouel et al., "Application of bacteriocins in the control of foodborne pathogenic and spoilage bacteria," 2008

[6] L. Settanni, and A. Corsetti, "Application of bacteriocins in vegetable food biopreservation," International journal of food microbiology, vol. 121, no. 2, pp. 123-138, 2008

[7] P. Cotter, C. Hill, and R. Ross, "Bacteriocins: developing innate immunity for food," Nature Reviews Microbiology, vol. 3, no. 10, pp. 777-788, 2005.

[8] S. Draper, A. Moore, A. Goodman et al., "Effective induction of high-titer antibodies by viral vector vaccines," Nature medicine, vol. 14, no. 8, pp. 819-821, 2008

[9] S. Chakraborty, M. Roy, A. Taraphdar et al., "Cytotoxic effect of root extract of Tiliacora racemosa and oil of Semecarpus anacardium nut in human tumour cells," Phytotherapy Research, vol. 18, no. 8, pp. 595600, 2004.

[10] P. Foster, M. Martinez-Moczygemba, D. Huston et al. "Interleukins-4,-5, and-13: emerging therapeutic targets in allergic disease," Pharmacology \& therapeutics, vol. 94, no. 3, pp. 253-264, 2002.

[11] G. Cornut, C. Fortin, and D. Soulières, "Antineoplastic properties of bacteriocins: revisiting potential active agents," American journal of clinical oncology, vol. 31, no. 4, pp. 399, 2008.

[12] T. Takala, and P. Saris, "Nisin: Past, present, and future," Research and Applications in Bacteriocins, pp. 181, 2007.

[13] A. Rodas, S. Ferrer, and I. Pardo, "Polyphasic study of wine Lactobacillus strains: taxonomic implications," International journal of systematic and evolutionary microbiology, vol. 55, no. 1, pp. 197, 2005 .

[14] B. Forbes, D. Sahm, and A. Weissfeld, "Bailey \& Scott's diagnostic microbiology," 2002.

[15] M. Rogosa, R. Wiseman, J. Mitchell et al., "Species differentiation of oral lactobacilli from man including descriptions of Lactobacillus salivarius nov spec and Lactobacillus cellobiosus nov spec," Journal of Bacteriology, vol. 65, no. 6, pp. 681, 1953.

[16] M. Sharpe, "Taxonomy of the lactobacilli." p. 109.G. Davis, "The classification of lactobacilli from the human mouth," Microbiology, vol. 13 , no. 3, pp. 481, 1955.

[17] G. Davis, "The classification of lactobacilli from the human mouth," Microbiology, vol. 13, no. 3, pp. 481, 1955

[18] U. Schillinger, and F. Lücke, "Identification of lactobacilli from meat and meat products," Food Microbiology, vol. 4, no. 3, pp. 199-208, 1987.

[19] D. Hoover, and S. Harlander, "Screening methods for detecting bacteriocin activity," Bacteriocins of Lactic Acid Bacteria, pp. 23-39, 1993.

[20] A. Bhunia, M. Johnson, and B. Ray, "Purification, characterization and antimicrobial spectrum of a bacteriocin produced by Pediococcus acidilactici," Journal of Applied Microbiology, vol. 65, no. 4, pp. 261268, 1988.

[21] A. Geis, J. Singh, and M. Teuber, "Potential of lactic streptococci to produce bacteriocin," Applied and Environmental Microbiology, vol. 45, no. 1, pp. 205, 1983.

[22] S. Barefoot, and T. Klaenhammer, "Detection and activity of lactacin B, a bacteriocin produced by Lactobacillus acidophilus," Applied and Environmental Microbiology, vol. 45, no. 6, pp. 1808, 1983.

[23] T. Toba, S. Samant, E. Yoshioka et al., "Reutericin 6, a new bacteriocin produced by Lactobacillus reuteri LA 6," Letters in Applied Microbiology, vol. 13, no. 6, pp. 281-286, 1991.

[24] J. Sambrook, and D. Russell, Molecular cloning: a laboratory manual: Cold Spring Harbor Laboratory Pr, 2001.

[25] O. Lowry, N. Rosebrough, A. Farr et al., "Protein measurement with the Folin phenol reagent," J biol chem, vol. 193, no. 1, pp. 265-275, 1951.D. Darling, and S. Morgan, Animal cells: culture and media: Wiley, 1994.
[26] C. Delaney, L. Wang, S. Kyle et al., "Potentiation of temozolomide and topotecan growth inhibition and cytotoxicity by novel poly (adenosine diphosphoribose) polymerase inhibitors in a panel of human tumor cell lines," Clinical Cancer Research, vol. 6, no. 7, pp. 2860,2000 .

[27] D. Darling, and S. Morgan, Animal cells: culture and media: Wiley, 1994.

[28] R. Freshney, "Culture of animal cells: a manual of basic technique New York: Alan R. Liss," Inc., 1994.

[29] Y. Sang, and F. Blecha, "Antimicrobial peptides and bacteriocins: alternatives to traditional antibiotics," Animal Health Research Reviews, vol. 9, no. 02, pp. 227-235, 2008.

[30] S. Gilliland, and M. Speck, "Antagonistic action of Lactobacillus acidophilus toward intestinal and food borne pathogens in associative cultures," Journal of Food Protection (USA), 1977

[31] J. Tagg, A. Dajani, and L. Wannamaker, "Bacteriocins of grampositive bacteria," Microbiology and Molecular Biology Reviews, vol. 40 , no. 3, pp. 722, 1976.

[32] N. Stern, E. Svetoch, B. Eruslanov et al., "Isolation of Lactobacillus salivarius strain and purification of its bacteriocin, which is inhibitory to Campylobacter jejuni in the chicken gastrointestinal system," Antimicrobial agents and chemotherapy, vol. 50, no. 9, pp. 3111, 2006.

[33] N. Papo, and Y. Shai, "Host defense peptides as new weapons in cancer treatment," Cellular and Molecular life sciences, vol. 62, no. 7,pp. 784-790, 2005. 